\title{
Molecular and functional characteristics of dominant follicles during spring transition in mares: a review
}

\author{
Elaine D. Watson', Sung-Eun Bae ${ }^{7}$ and David G. Armstrong ${ }^{2}$ \\ University of Edinburgh, Royal (Dick) School of Veterinary Studies' ${ }^{1}$ and Roslin Institute (Edinburgh)2 ${ }^{2}$ Midlothian, UK
}

\begin{abstract}
Summary
Many mares enter a period of spring transition between winter anoestrus and cyclicity when follicles may reach preovulatory size, yet fail to ovulate. The aim of the present study was to determine the morphological, functional and molecular characteristics of large dominant transitional follicles. Follicle growth was monitored regularly from February through July in 25 pony mares. In some of the mares, one of the ovaries was removed on the day after an anovulatory follicle reached $30 \mathrm{~mm}$, and the contralateral ovary was removed during cyclicity on the day after the preovulatory follicle reached $30 \mathrm{~mm}$. Samples of the large follicle were processed for immunohistochemistry and in situ hybridisation, and follicular fluid was frozen. Hormonal control of growth of the large transitional follicles was similar to that seen during cyclicity. However concentrations of oestradiol were significantly lower than during growth of the preovulatory follicle and LH remained low until ovulation. During growth of anovulatory follicles, uterine oedema was sometimes present along with low, but significant, elevations in oestradiol. Transitional follicles had poorly developed theca that received a scant blood supply and there was little VEGF, the main ovarian angiogenic factor, in these follicles. Transitional follicles contained only low concentrations of oestradiol and progesterone and there was low expression of mRNA encoding StAR, the steroidogenic enzymes, and LHr in the follicle walls. Our results show that the poor steroidogenic capacity of transitional follicles is directly related to low gene expression of the steroidogenic enzymes, possibly caused by the low levels of LHr and IGF mRNAs. The scant blood supply and poor development of the theca would also contribute to the steroidogenic incompetence of these follicles. Expression of IGF-I and -II mRNAs were lower in transitional anovulatory follicles than in preovulatory follicles and intrafollicular concentrations of IGFBP-2 were significantly higher in transitional than in preovulatory follicles. These results suggest that the bioavailability of intrafollicular IGF is enhanced in large preovulatory follicles during the breeding season and suggests that intrafollicular IGF bioavailability must exceed a threshold level before an ovulation can occur.
\end{abstract}

Keywords: follicles, transition, hormones, IGF, mare

Molekulare und funktionelle Charakterisierung der dominanten Follikel in den Übergangszyklen im Frühjahr bei Stuten eine Übersicht

Viele Stuten zeigen im Frühjahr, zwischen dem Winteranöstrus und der zyklischen Aktivität, eine Übergangsperiode in der die Follikel zwar präovulatorische Größe erreichen, aber nicht ovulieren. Das Ziel der vorliegenden Studie war die morphologische, funktionelle und molekularbiologische Charakterisierung großer dominanter Follikel in der Übergangszeit. Dazu wurde bei 25 Ponystuten zwischen Februar und Juli das Follikelwachstum regelmäßig kontrolliert. Bei einigen der Stuten wurde ein Ovar am Tag nachdem ein anovulatorischer Follikel 30 $\mathrm{mm}$ groß war enfernt, das kontralaterale Ovar wurde während des Zyklus, einen Tag nach Erreichen eines 30 mm großen präovulatorischen Follikels entnommen. Proben der großen Follikel wurden immunhistochemisch und mittels inSitu-Hybridisierung beurteilt und die Follikelflüssigkeit wurde tiefgefroren. Die hormonelle Kontrolle des Wachstums der großen Follikel in der Übergangszeit entsprach der während des Zyklus mit einem Anstieg von FSH und Inhibin A im Zusammenhang mit dem Wachstum eines dominanten Follikels. Die Östradiolkonzentrationen waren hingegen signifikant niedriger als während der Entwicklung eines präovulatorischen Follikels und LH blieb bis zur Ovulation niedrig. Während des Wachstums eines anovulatorischen Follikels trat in einigen Fällen ein uterines Ödem zusammen mit einem geringen, aber signifikanten Anstieg von Östradiol, auf. Die Follikel in der Übergangsphase zeigten eine wenig ausgeprägte Theka mit schwacher Blutversorgung und wenig VEGF, dem hauptsächlichen ovariellen angiogenetischen Faktor in diesen Follikeln. Die Übergangsfollikel enthielten nur geringe Mengen an Östradiol und Progesteron und die mRNA von StAR, den steroidogenen Enzymen, und von LHr wurde in den Follikelwänden nur geringgradig nachgewiesen. Die Ergebnisse zeigen, daß die niedrige steroidogene Kapazität der Übergangsfollikel in direktem Zusammenhang mit der niedrigen Genexpression der steroidogenen Enzyme, möglicherweise aufgrund des niedrigen Niveaus an LH- und IGF-mRNA, steht. Die geringere Blutversorgung und die schwächer entwickelte Theka führen möglicherweise ebenfalls zu der steroidogenen Inkompetenz dieser Follikel. Die Expression der IGF-I und -II mRNA war in den anovulatorischen Übergangsfollikeln niedriger als in präovulatorischen Follikeln, und die intrafollikulären Konzentrationen von IGFBP-2 erwiesen sich aös significant höher in Übergangsfollikeln als in pröovulatorischen Follikeln. Diese Ergebnisse lassen vermuten, dass die Bioverfügbarkeit des intrafollikulären IGF in den großen präovulatorischen Follikeln während der Zuchtsaison erhöht ist und eine Mindestkonzentration erreicht haben muss, bevor eine Ovulation statt finden kann.

Schlüsselwörter: Reproduktion, Follikel, Übergangszyklus, Hormone, IGF, Stute

\section{Introduction}

The mare is seasonally polyoestrus, with the natural breeding season extending from May to October (Ginther 1974). During winter anoestrus, the hypothalamo-pituitary axis is essentially non-functional. GnRH secretion is greatly reduced, possibly via dopaminergic inhibition (Besognet et al. 1996), and the pituitary fails to release significant amounts of gonadotrophins (Hart et al. 1984). Pituitary content of LH is low, but FSH content is unchanged. In response to the low con- 
centrations of circulating gonadotrophins during winter anoestrus, mares have small, hard ovaries. In spring transition, follicles initially grow and regress, but do not exceed $35 \mathrm{~mm}$ in diameter (Ginther 1990). In many mares, waves of anovulatory follicle development then proceed, characterised by serial growth and regression of large $(>38 \mathrm{~mm})$ dominant follicles which are steroidogenically-incompetent. When a dominant oestrogenic follicle develops in the ovaries, the high circulating concentrations of oestradiol induce increased synthesis and secretion of $\mathrm{GnRH}$ and/or pituitary LH subunit mRNA expression (Sharp et al. 2001). This results in release of $\mathrm{LH}$ in sufficient amounts to cause ovulation (Sharp et al. 1991). Little was known in dominant transitional follicles of the factors thought to be critical to follicle maturation and ovulation: patterns of circulating FSH and inhibin A, steroidogenic enzymes, vascularity, morphology, and the IGF system.

Inhibin is thought to be important in control of $\mathrm{FSH}$ secretion and follicular growth in mares (McCue et al. 1992, Nambo et al. 1998). A number of studies have reported circulating concentrations of immunoreactive inhibin in cyclic mares (Bergfelt et al. 1991, Nagamine et al. 1998). These assays do not distinguish between the biologically active dimeric forms of inhibin and free monomeric a-subunits, which are thought not to be biologically active, and can antagonise the actions of FSH on granulosa cells by binding to FSH receptors (Schneyer et al. 1991). Immunoreactive inhibin and inhibin isoforms with pro- and -aC immunoreactivity, increase in late dioestrus in mares and peak on the day of ovulation (Bergfelt et al. 1991, Nagaoka et al. 1999). However no information was available on hormonal control of follicular development in transitional mares.

The steroidogenic potential of follicles depends upon the presence of gonadotrophin receptors, the availability of cholesterol, regulated by StAR, and the activity of rate-limiting steroidogenic enzymes. In order to investigate whether these were deficient in transitional follicles, levels of mRNA encoding the steroidogenic enzymes, StAR and LHr were compared in large follicles collected during spring transition and the breeding season using in situ hybridization, which gave information on both spatial distribution and levels of the respective mRNAs.

Blood vessel development serves a crucial role in follicular maturation (Richards 1980), and during follicle growth, a rich capillary plexus develops in the thecal layer surrounding the avascular granulosa cells. Work in primates has shown that the density of the microvascular network of follicles destined to ovulate is at least double that of follicles destined to become atretic (Zeleznik et al. 1981). This increased vascularity results in greater delivery of gonadotrophins to preovulatory follicles. Vascular endothelial growth factor (VEGF) is a multifunctional cytokine stimulating blood vessel formation and enhancing microvascular permeability (Dvorak et al. 1995). Expression of VEGF mRNA and protein has been reported in follicles and corpora lutea of various species (Barboni et al. 2000, Kashida et al. 2001, Ravindranath et al. 1992). However, very little was known about the relative vascularity of equine ovulatory and anovulatory transitional follicles although it is clear that degree of vascularisation may be a critical factor in determining their subsequent fate.

Growth factors, in particular the insulin-like growth factor (IGF) system, are thought to play a key role in ovarian folli- cular growth and atresia. The IGFs have a variety of effects on follicular and luteal cells including stimulation of steroidogenesis, via increased availability of steroid precursors and upregulation of steroidogenic enzyme expression and activity. Follicular concentrations of IGF-I increase in large equine follicles (Bridges et al. 2002), whereas IGF-II concentrations are not different among different sizes of follicle. IGF binding proteins (IGFBPs) present within the ovary bind with IGFs, prolonging the half-life, but blocking the biological action of the IGFs (for review see Armstrong and Webb 1997). Follicular concentrations of IGFBP-2 decrease during follicular growth and increase during atresia in most species, including horses (Gerard and Monget 1998). We hypothesized, therefore, that the bioavailability of IGF would be lower during spring transition, when follicles grow to preovulatory size but fail to ovulate, contributing to failure of normal follicular steroidogenesis and development at this time.

This paper presents results from a series of studies designed to give a detailed insight into the structure and function of transitional anovulatory follicles in mares.

\section{Materials and Methods}

Twenty five mares of mixed breeding, weighing 250-450 kg and aged $3-20$ years (mean \pm SEM: $9 \pm 1.6$ years), were studied from the beginning of February through to their second or third ovulation of the breeding season. Ovarian activity was monitored three times weekly by transrectal ultrasonography until detection of the first $25 \mathrm{~mm}$ follicle on the ovaries, when examinations were performed daily until first ovulation. Blood samples were collected by jugular venipuncture into evacuated heparinised tubes three times weekly until follicles of $20 \mathrm{~mm}$ were present in the ovaries, when blood samples were collected daily until first ovulation. Examinations and blood sampling then resumed on day 14 after ovulation until second ovulation. The ovary containing the dominant follicle was removed from 14 of the mares during one of the anovulatory follicular waves in spring transition on the day after the leading follicle reached $30 \mathrm{~mm}$ in diameter. The contralateral ovary was removed at the second or third ovulation of the breeding season on the day after the dominant follicle reached $30 \mathrm{~mm}$ in diameter. After ovary removal, follicular fluid was aspirated from the largest and second largest follicles by needle puncture. A portion of follicle wall was fixed in $4 \%$ paraformaldehyde for $24 \mathrm{~h}$ until paraffin embedding. Histological sections were subsequently stained with haematoxylin and eosin.

Hormone assays, immunostaining, in situ hybridization, and Western ligand blots were carried out as described previously (Xu et al. 1995, Armstrong et al. 1998, Nicholas et al. 2002, Watson et al. 2002a,b).

\section{Results}

During spring transition there was an average of $3.7 \pm 0.7$ waves with dominant follicles of $>30 \mathrm{~mm}$, at intervals of 9.9 \pm 0.8 days. In all transitional mares, each follicle wave was preceded by a significant elevation $(\mathrm{P}<0.001)$ in FSH. The increase in FSH was observed when the follicle reached 15 $22 \mathrm{~mm}$. Two days later the follicles were 20-24 mm in diameter. However concentrations of FSH did fluctuate during 
spring transition and some peaks were found that were not apparently associated with initiation of follicular growth.

Concentrations of plasma oestradiol consistently reached higher levels $(P<0.01)$ during the growth of an anovulatory follicle than in the three days before and after this time. Any peak in oestradiol concentrations was, however, short-lived and decreased as soon as the follicle started to regress. During the growth phase of an anovulatory follicle, concentrations of inhibin $\mathrm{A}$ and inhibin pro- and -aC-containing isoforms were significantly higher $(P<0.05)$ than in deep winter anoestrus. In spring transition there were negative correlations between plasma inhibin pro-aC isoforms and $\mathrm{FSH}(\mathrm{P}=$ $0.06)$ and between plasma inhibin $A$ and $F S H(P=0.1)$ which approached significance.

Mean peak concentrations of FSH at the time of emergence of the first preovulatory follicles were not significantly different to those measured at time of emergence of anovulatory follicles for the same mares in spring transition. The peak concentration was significantly higher $(P<0.001)$ than that measured 2 days later. At this time the diameter of the dominant follicle was 21-32 mm which was not significantly different from the growth rate of the anovulatory follicles. Over the 10 days prior to the first ovulation, circulating concentrations of oestradiol, inhibin $\mathrm{A}$ and inhibin pro-aC isoforms increased gradually, with oestradiol peaking 2 days before ovulation, and inhibin pro- and - $\mathrm{aC}$ isoforms peaking on day of ovulation.

In cyclic mares, mean concentration of oestradiol during growth of an ovulatory follicle was significantly higher $(\mathrm{P}<$ $0.001)$ than during the growth of an anovulatory follicle. Plasma concentrations of inhibin A were significantly higher ( $P$ $<0.05)$ during growth of a preovulatory follicle than during growth of an anovulatory follicle in spring transition (see Watson et al. 2002a). Concentrations of oestradiol, progesterone and inhibin A were significantly lower in fluid collected from dominant, anovulatory transitional follicles than from preovulatory follicles. Although inhibin pro- and -aC isoforms tended to decrease in preovulatory follicles compared with transitional anovulatory follicles, these differences were not significant (see Watson et al. 2002b).

Eleven mares that had serial large anovulatory follicles, had uterine oedema at some point prior to their first ovulatory oestrus of the breeding season. The oedema was first detected 16 to 86 days before first ovulation. In mares that did not have anovulatory follicle waves, there was no detectable uterine oedema prior to first ovulatory oestrus. During anovulatory follicle waves, oestradiol concentrations were higher $(P<$ 0.05) on days when uterine oedema was observed than on consecutive days when uterine oedema was not present. Peak plasma oestradiol concentrations and mean oestradiol concentrations during growth of the dominant follicle $>25 \mathrm{~mm}$ were significantly higher $(\mathrm{P}<0.001)$ during growth of follicles at first and second ovulation than during the growth of an anovulatory wave (see Watson et al. 2003a)

Histology

Both anovulatory and preovulatory follicles had a well organised layer of granulosa cells in contact with the basement membrane. The theca interna in preovulatory follicles comprised a thick layer of plump polyhedral cells with a pale nucleus and cytoplasm, whereas the theca layer of the anovulatory follicles was thin and poorly developed in most parts with only sparse foci of polyhedral cells (see Watson and Alzi'abi 2002).

\section{Vascularity}

Immunostaining for VEGF was confined to the theca interna. In preovulatory follicles, the entire theca interna layer stained strongly and diffusely for VEGF. Immunostaining in the transitional follicles was scant with patchy staining in the thin theca layer. Immunostaining for von Willebrand Factor (vWF) was confined to endothelial cells of blood vessels in the theca interna. The theca was well supplied with blood vessels in the preovulatory follicles whereas the transitional follicles had a relatively avascular theca. A significantly greater $(P<0.05)$ area of tissue was stained for VWF in the preovulatory follicles than in the transitional follicles. Positive staining for Ki67 (proliferation) was confined to cell nuclei and was frequently present in the granulosa cells and thecal endothelial cells of preovulatory follicles. No staining was seen in endothelial cells of transitional follicles and only occasional granulosa cells were stained (see Watson and Al-zi'abi 2002).

\section{Steroidogenic enzymes and $\mathrm{LHr}$}

There was significantly lower $(P<0.001)$ expression of StAR and steroidogenic enzymes in transitional follicles than in preovulatory follicles. Expression of LHr mRNA was lower in both granulosa $(P<0.05)$ and theca $(P<0.001)$ cells in transitional than preovulatory follicles (see Watson et al. 2003b).

\section{IGF System}

Levels of IGFBP-2 were significantly higher $(P<0.05)$ in fluid from transitional follicles than in fluid from preovulatory follicles. Expression of mRNAs encoding IGF-I and -II was significantly lower $(P<0.001)$ in transitional anovulatory follicles than in preovulatory follicles (Bae et al. 2003). In transitional follicles, IGFBP-2 mRNA expression was similar in theca and granulosa cells. There was a significant increase $(P<$ 0.001 ) in thecal expression in preovulatory follicles compared with transitional follicles, whereas expression in granulosa remained unchanged.

\section{Discussion}

In these studies, during spring transition there was an average of 3.7 waves with leading follicles of $>30 \mathrm{~mm}$, at intervals of approximately 10 days. This pattern was very similar to that previously reported by workers in Florida and Wisconsin (Davis et al. 1987, Ginther 1990). Concentrations of FSH were low in mares in deep winter anoestrus when the ovaries were small and hard with minimal follicular activity, and increased by the time the mares had significant follicular activity on their ovaries. These findings are in agreement with previous reports (Turner et al. 1979, Alexander and Irvine 1991). We found that the emergence of every dominant follicle, anovulatory or ovulatory, was preceded by an FSH surge when the follicle was $15-23 \mathrm{~mm}$ in diameter, suggesting 
that follicular wave emergence is stimulated by FSH regardless of season. This has been confirmed by a later paper (Donadeu and Ginther 2002). In the presence of anovulatory follicle waves in spring, circulating concentrations of inhibin $A$ were higher than in anoestrus, but were significantly lower than during the same period of growth of an ovulatory follicle (Watson et al. 2002a). Furthermore, in contrast to preovulatory follicles which contained high concentrations of circulating inhibin A, large anovulatory transitional follicles in our mares contained significantly lower concentrations of inhibin A (Watson et al. 2002b). The absence of large follicles in deep anoestrus may explain the low circulating concentrations of the isoforms of inhibin measured in the present study. During winter anoestrus, greater variations were seen in FSH than during cyclicity, and so perhaps the absence of suppression by high circulating concentrations of inhibin A permitted intermittently elevated concentrations of $\mathrm{FSH}$ at this time.

We have shown in these studies, in agreement with Davis and Sharp (1991), that anovulatory follicles are not associated with high circulating concentrations of oestradiol. However, there was a clear significant elevation in concentrations of both oestradiol and inhibin A during anovulatory waves compared with periods when no large follicles were present. Furthermore, we showed a significant decrease in FSH as the dominant follicle grew after emergence. Therefore, we would suggest that the combined effect of inhibin and oestradiol, which is more strongly inhibitory than either hormone on its own (Miller et al. 1981), may be important in suppressing the pituitary release of $\mathrm{FSH}$ that was measured during spring transition when the dominant anovulatory follicle reached a mean of $22 \mathrm{~mm}$ in diameter. The similarity in diameter and in hormonal patterns between dominant spring transition and during the breeding season strongly suggests that these large anovulatory follicles show dominance in a similar manner to follicles during the oestrous cycle. In the present studies, concentrations of inhibin A were higher in preovulatory follicles than in either transitional or subordinate follicles. As the fate of both transitional and subordinate follicles in mares is regression, it is possible that the elevated concentrations of inhibin $A$ in the preovulatory follicles of mares are anti-atretogenic. Alternatively inhibin A may be involved in the process of ovulation.

The small elevations in oestradiol concentrations during the growth of anovulatory follicle waves, were sometimes associated with uterine oedema. It seems likely therefore that in the absence of progesterone, the mare is highly sensitive to very low concentrations of oestrogen during spring transition at the level of both the brain and the uterus. The presence of oestrous-like uterine oedema during anovulatory waves means that oedema cannot be used as definite proof that a large follicle is destined to ovulate (Watson et al. 2003a).

Poor vascularity, characterised by visibly pale follicular walls, has been reported to be a sign of atresia in equine follicles (Kenney et al. 1979). In the present study, the lining of transitional follicles was paler than that of preovulatory follicles. This observation was confirmed by immunostaining for vWF which identifies endothelial cells. There was a significantly smaller area of vWF immunostaining in the theca of transitional than preovulatory follicles. The results of the present stu- dy therefore indicate increased vascularity in the preovulatory follicles compared with transitional follicles (Watson and Alzi'abi 2002). Furthermore, the transitional follicles contained very little VEGF, which is important in promoting angiogenesis, whereas VEGF appeared to be abundant in the preovulatory follicles. VEGF also has the ability to increase the permeability of the microvasculature (Murohara et al. 1998). Thus in preovulatory follicles, the richer blood supply, in combination with increased permeability of blood vessels, will allow increased provision of oxygen, nutrients and substrates, as well as circulating gonadotrophins, which are essential for follicular health, growth, and steroidogenesis.

The growth of new blood vessels can also be monitored by measuring endothelial cell proliferation (Rodger et al. 1997). Cells with the morphological appearance of endothelial cells that stained positively for Ki67 were present only in the theca of preovulatory follicles, suggesting active proliferation of blood vessels in these follicles. Many of the granulosa cells in these follicles were also positively stained, whereas staining was infrequent in the granulosa of the transitional follicles indicating active cell division in the preovulatory follicles in contrast to the transitional follicles.

As follicle health and growth is dependent on gonadotrophin stimulation, it is likely that the low circulating concentrations of $\mathrm{LH}$ failed to stimulate adequate production of angiogenic factors, including VEGF. The low levels of angiogenic factors then led to poor thecal vascularisation and vascular permeability, both of which are essential for trophic support of the actively dividing follicular cells. Poor vascularity in turn will contribute to inadequate delivery of gonadotrophins and other trophic factors to the follicle to sustain development. In these mares therefore, the low levels of thecal VEGF could result in failure of further development and subsequent atresia of transitional follicles.

The low levels of mRNAs for steroidogenic enzymes found in transitional follicles in these studies, indicate that oestrogen production in transitional follicles is compromised by both a reduction in the supply of aromatizable substrate in thecal tissue and reduced aromatase activity in granulosa cells. At the ovarian level, it has been shown that the acquisition of steroidogenic competence by a large dominant follicle precedes initiation of cyclicity in transitional mares by approximately 5.5 days (Sharp et al. 2001). These authors suggested that increases in oestradiol concentrations may be the key factor in stimulating release of $\mathrm{LH}$ prior to first ovulation. In larger follicles, expression of $\mathrm{LHr}$ and $\mathrm{LH}$ binding increase (Fay and Douglas 1987, Goudet et al. 1999). This is accompanied by an increase in steroidogenic enzymes and concentrations of oestradiol in follicular fluid (Watson and Thomson 1996, Belin et al. 2000). In the present study, mRNA encoding $\mathrm{LHr}$ was low in transitional follicles. Final follicular growth and development in the mare is dependent on support by $\mathrm{LH}$ (Gastal et al.1999, Watson et al. 2000). It is likely therefore that both the low circulating concentrations of LH and low expression of follicular $\mathrm{LHr}$ in transitional mares contributed to the deficiency in mRNAs for the steroidogenic enzymes.

Intrafollicular concentrations of IGF-I, but not IGF-II, have been positively correlated with follicle size in mares (Spicer et al. 1991, Bridges et al. 2002) and concentrations are higher 
in follicles that assume dominance (Ginther et al. 2002). IGFI stimulates mitogenesis, steroidogenesis and upregulates gonadotrophin receptors (Armstrong and Webb 1997). In other domestic species, changes in IGFBP concentrations are more closely associated with follicle growth and regression than with changes in levels of IGF-I and -II (Spicer and Echternkamp 1995), because only free IGF has biological activity. In mares, intrafollicular levels of IGFBP-2, -4, and -5 decrease in large, oestrogenically-active dominant follicles compared with subordinate follicles or large regressing follicles which contain only low concentrations of oestrogen (Gerard and Monget 1998, Bridges et al. 2002). Therefore it has been proposed that follicular levels of these binding proteins are closely related to the physiological status of equine follicles. Although there was a significant increase in IGFBP-2 mRNA in theca of preovulatory follicles, concentrations of IGFBP-2 were lower in preovulatory follicles than in transitional follicles. One explanation of the discrepancy between message and protein would be the presence of IGFBP-2 protease activity in follicular fluid of preovulatory follicles. However in equine follicular fluid it is thought that there is little or no proteolysis of IGFBP-2 (Bridges et al. 2002). The high levels of IGFBP-2 in transitional follicles, by lowering free IGF concentrations, may contribute to the steroidogenic inadequacy of these follicles. Reduced availability of IGF may also contribute to the low LH receptor mRNA expression (Magoffin and Weitsman 1994; Watson et al. 2003b), and the low levels of VEGF and proliferation in dominant transitional follicles (Watson and Al-zi'abi 2002, Martinez-Chequer et al. 2003).

We conclude that the poor steroidogenic capacity of transitional follicles is directly related to low gene expression of the steroidogenic enzymes, possibly caused by the low levels of $\mathrm{LHr}$ and bioavailability of IGF. The low levels of VEGF in transitional follicles are likely to have resulted in the scant blood supply and poor development of the theca which would also contribute to the steroidogenic incompetence of these follicles.

\section{Acknowledgements}

These studies were funded by the Horserace Betting Levy Board, Project No 666. We thank Dr A.F. Parlow, National Hormone and Pituitary Programme, Torrance, CA for kindly providing the FSH antigen and antibody. We are indebted to the following for the contributions that they made to this work: O. Al-zi'abi, N. Groome, M. Hanks, M. Heald, C. Hogg, R Leask, S. Melling, E. Nikolakopoulos, D. Pearce, S. Riley, O. Sheerin, M. Steele, R. Thomassen, S. Thomson and A. Tsigos.

\section{Literature}

Alexander S. L. and Irvine C. H. G. (1991): Control of onset of breeding season in the mare and its artificial regulation by progesterone treatment. Journal of Reproduction and Fertility Supplement 44, 307-319

Armstrong D. G. and Webb R. (1997): Ovarian follicular dominance: the role of intraovarian growth factors and novel proteins. Reviews of Reproduction 2, 139-146
Armstrong D. G., Baxter G., Gutierrez C. G., Hogg C. O., Galzyrin A. L., Campbell B. K., Bramley T. A. and Webb R. (1998): Insulinlike growth factor binding protein-2 and -4 messenger ribonucleic acid expression in bovine ovarian follicles: effect of gonadotropins and developmental status. Endocrinology 139, 2146-2154

Bae S.-E., Steele M., Thomassen R., Hogg C. O., Thomson S., Armstrong D. G. and Watson E. D. (2003): Expression of mRNAs encoding IGFs and IGF binding proteins in equine follicles during spring transition and the breeding season. Reproduction Abstr Ser No 30, 063

Barboni B., Turriani M., Galeati G., Spinaci M., Bacci M. L., Forni M. and Mattioli M. (2000): Vascular endothelial growth factor production in growing antral pig follicles. Biology of Reproduction 63. 858-864

Belin F., Goudet G., Duchamp G. and Gerard N. (2000): Intrafollicular concentrations of steroids and steroidogenic enzymes in relation to follicular development in the mare. Biology of Reproduction 62, 1335-1343

Bergfelt D. R., Mann B. G., Schwartz N. B. and Ginther O. J. (1991): Circulating concentrations of immunoreactive inhibin and FSH during the estrous cycle of mares. Journal of Equine Veterinary Science 11, 319-322

Besognet B., Hansen B. S. and Daels P. F. (1996): Dopaminergic regulation of gonadotrophin secretion in seasonally anoestrous mares Journal of Reproduction and Fertility 108, 55-61

Bridges T. S., Davidson T. R., Chamberlain C. S., Geisert R. D. and Spicer L. J. (2002): Changes in follicular fluid steroids, insulin-like growth factors (IGF) and IGF-binding protein concentration, and proteolytic activity during equine follicular development. Journal of Animal Science 80, 179-190

Davis S. D. and Sharp D. C. (1991): Intra-follicular and peripheral steroid characteristics during vernal transition in the pony mare. Journal of Reproduction and Fertility Supplement 44, 333-340

Davis S. D., Grubaugh W. R. and Withenauer J. (1987): Follicle integrity and serum estradiol $17 \mathrm{~b}$ patterns during sexual recrudescence in the mare. Biology of Reproduction 36, Supplement 1, 143 Abstr.

Donadeu F. X. and Ginther O. J. (2002): Follicular waves and circulating concentrations of gonadotrophins, inhibin and oestradiol during the anovulatory season in mares. Reproduction 124, 875 885

Dvorak H. F., Brown L. F., Detmar M. and Dvorak A. M. (1995): Vascular permeability factor/vascular endothelial growth factor, microvascular hyperpermeability, and angiogenesis. American Journal of Pathology 146, 1029-1039

Fay J. E. and Douglas R. H. (1987): Changes in thecal and granulosa cell LH and FSH receptor content associated with follicular fluid and peripheral plasma gonadotrophin and steroid hormone concentrations in preovulatory follicles of mares. Journal of Reproduction and Fertility Supplement 35, 169-181

Gastal E. L., Gastal M. O., Wiltbank M. C. and Ginther O. J. (1999): Follicle deviation and intrafollicular and systemic estradiol concentrations in mares. Biology of Reproduction 61, 31-39

Gerard N. and Monget P. (1998): Intrafollicular insulin-like growth factor-binding protein levels in equine ovarian follicles during preovulatory maturation and regression. Biology of Reproduction 58, 1508-1514

Ginther O. J. (1974): Occurrence of anestrus, estrus, diestrus, and ovulation over a 12 -month period in mares. American Journal of Veterinary Research 35, $1173-1179$

Ginther O. J. (1990): Folliculogenesis during the transitional period and early ovulatory season in the mare. Journal of Reproduction and Fertility 90, $311-320$

Ginther O. J., Meira C., Beg M. A. and Bergfelt D. R. (2002): Follicle and endocrine dynamics during experimental follicle deviation in mares. Biology of Reproduction 67, 862-867

Goudet G., Belin F., Bezard J. and Gerard N. (1999): Intrafollicular content of luteinizing receptor, a-inhibin, and aromatase in relation to follicular growth, estrous cycle stage, and oocyte competence for in vitro maturation in the mare. Biology of Reproduction $60,1120-1127$ 
Hart P. J., Squires E. L., Imel K. J. and Nett T. M. (1984): Seasonal variation in hypothalamic content of gonadotrophin-releasing hormone $(\mathrm{GnRH})$, pituitary receptors for $\mathrm{GnRH}$, and pituitary content of luteinizing hormone in the mare. Biology of Reproduction 30, 1055-1062

Kashida S., Sugino N., Takiguchi S., Karube A., Takayama H., Yamagata Y., Nakamura Y. and Kato H. (2001): Regulation and role of vascular endothelial growth factor in the corpus luteum during mid-pregnancy in rats. Biology of Reproduction 64, 317-323

Kenney R. M., Condon W., Ganjam V. K. and Channing C. (1979): Morphological and biochemical correlates of equine ovarian follicles as a function of their state of viability or atresia. Journal of Reproduction and Fertility Supplement 27, 163-171

Magoffin D. A. and Weitsman S. R. (1994): Insulin-like growth factor-I regulation of luteinizing hormone (LH) receptor messenger ribonucleic acid expression and LH-stimulated signal transduction in rat ovarian theca interstitial cells. Biology of Reproduction 51, 766-775

Martinez-Chequer J. C., Stouffer R. L., Hazzard T. M., Patton P. E. and Molskness T. A. (2003): Insulin-like growth factors-1 and -2, but not hypoxia, synergize with gonadotropin hormone to promote vascular endothelial growth factor-A secretion by monkey granulosa cells from preovulatory follicles. Biology of Reproduction 68, $1112-1118$

McCue P. M., Canney N. J., Hughes J. P., Rivier J., Vale W. and Lasley B. L. (1992): Ovulation and embryo recovery rates following immunization of mares against an inhibin a-subunit fragment. Theriogenology 38, 823-831

Miller K. F., Wesson J. A. and Ginther O. J. (1981): Interaction of estradiol and nonsteroidal follicular fluid substance in the regulation of gonadotropin secretion in the mare. Biology of Reproduction 24, 354-358

Murohara T., Horowitz J. R., Silver M., Tsurumi Y., Chen D., Sullivan A. and Isner J. M. (1998): Vascular endothelial growth factor/vascular permeability factor enhances vascular permeability via nitric oxide and prostacyclin. Circulation 97, 99-107

Nagamine N., Nambo Y., Nagata S.-l., Nagaoka K., Tsunoda N., Taniyama H., Tanaka Y., Tohei A., Watanabe G. and Taya K. (1998): Inhibin secretion in the mare: Localization of inhibin $a, b_{A^{\prime}}$ and $b_{B}$ subunits in the ovary. Biology of Reproduction 59, 13921398

Nagaoka K., Nambo Y., Nagamine N., Nagata S.-I., Tanaka Y., Shinbo H., Tsunoda N., Taniyama H., Watanabe G., Groome N. P. and Taya K. (1999): A selective increase in circulating inhibin and inhibin pro-aC at the time of ovulation in the mare. American Journal of Physiology 277, E870-E875

Nambo Y., Kaneko H., Nagata S., Oikawa M., Yoshihara T., Nagamine N., Watanabe G. and Taya K. (1998): Effect of passive immunization against inhibin on FSH secretion, folliculogenesis and ovulation rate during the follicular phase of the estrous cycle in mares. Theriogenology 50, 545-557

Nicholas B., Scougall R. K., Armstrong D. G. and Webb R. (2002): Changes in insulin-like growth factor binding protein (IGFBP) isoforms during bovine follicular development. Reproduction 124, 439-446

Ravindranath N., Little-Ihrig L., Phillips H. S., Ferrara N. and Zeleznik A. J. (1992): Vascular endothelial growth factor messenger ribonucleic acid expression in the primate ovary Endocrinology 1, 254-260

Richards J. S. (1980): Maturation of ovarian follicles: action and interaction of pituitary and ovarian hormones on follicular cell differentiation. Physiological Reviews 60, 51-89

Rodger F. E., Young F. M., Fraser H. M. and Illingworth P. J. (1997): Endothelial cell proliferation follows the mid-cycle luteinizing hormone surge, but not human chorionic gonadotrophin rescue, in the human corpus luteum. Human Reproduction 12, 1723-1729

Schneyer A. L. Sluss P. M., Whitcomb R. W., Martin K. A., Sprengel R. and Crowley Jr W. F. (1991): precursors of alpha-inhibin modulate follicle-stimulating hormone receptor binding and biological activity. Endocrinology 129, 1987-1999
Sharp D. C., Grubaugh W. R., Weithenaver J., Davis S. D. and Wilcox C. J. (1991): Effect of steroid administration on pituitary luteinizing hormone and follicle-stimulating hormone in ovariectomized pony mares in the early spring: Pituitary responsiveness to gonadotropin-releasing hormone and pituitary gonadotropin content. Biology of Reproduction 44, 983-990

Sharp D. C., Wolfe M. W., Cleaver B. D. and Nilson J. (2001): Effects of estradiol-17b administration on steady-state messenger ribonucleic acid (mRNA) encoding equine a and LH/CGb subunits in pituitaries of ovariectomized mares. Theriogenology 55, 10831093

Spicer L. J. and Echternkamp S. E. (1995): The ovarian insulin and insulin-like growth factor system with an emphasis on domestic animals. Domestic Animal Endocrinology 12, 233-245

Spicer L. J., Tucker K. E., Henderson K. A. and Duby R. T. (1991): Concentrations of insulin-like growth factor-l in follicular fluid and blood plasma of mares during early and late oestrus. Animal Reproduction Science 25, 57-65

Turner D. D., Garcia M. C. and Ginther O. J. (1979): Follicular and gonadotropic changes throughout the year in pony mares. American Journal of Veterinary Research 40, 1694-1700

Watson E. D. and Al-zi'abi M. O. (2002): Characterisation of morphology and angiogenesis in follicles of mares during spring transition and the breeding season. Reproduction 124, 227-234

Watson E. D. and Thomson S. R. M. (1996): Immunohistological localisation of P450arom within the ovaries of pregnant and nonpregnant mares. Journal of Reproduction and Fertility 108, 239244

Watson E. D., Pedersen H. G., Thomson S. R. M. and Fraser H. M. (2000): Control of follicular development and corpus luteum function in the mare: Effects of a potent $\mathrm{GnRH}$ antagonist. Theriogenology 54, 599-609

Watson E. D., Heald M., Tsigos A., Leask R., Steele M., Groome N. P. and Riley S. C. (2002a): Plasma FSH, inhibin A and inhibin isoforms containing pro- and - $\mathrm{aC}$ in mares during winter anoestrus, spring transition and the breeding season. Reproduction 123, 535-542

Watson E. D., Thomassen R., Steele M., Heald M., Leask R., Groome N. P. and Riley S. C. (2002b): Concentrations of inhibin, progesterone and oestradiol in fluid from dominant and subordinate follicles from mares during spring transition and the breeding season. Animal Reproduction Science 74, 55-67

Watson E. D., Thomassen R. and Nikolakopoulos E. (2003a): Association of uterine edema with follicle waves around the onset of the breeding season. Theriogenology 59, 1181-1187

Watson E. D., Bae S. E., Steele M., Thomassen R., Pedersen H. G., Bramley T., Hogg C. O. and Armstrong D. G. (2003b): Effect of season on expression of messenger ribonucleic acid encoding steroidogenic enzymes and luteinizing hormone receptor in equine follicles. Submitted for publication

Xu Z. Z., Garverick H. A., Smith G. W., Smith M. F., Hamilton S. A. and Younquist R. S. (1995): Expression of messenger ribonucleic acid encoding cytochrome P450 side-chain cleavage, cytochrome P450 17a-hydroxylase, and cytochrome P450 aromatase in bovine follicles during the first follicular wave. Endocrinology 135, 981-989

Zeleznick A. J., Shuler H. M. and Reichert L. E. Jr (1981): Gonadotropin-binding site in the Rhesus monkey ovary: role of the vasculature in the selective distribution of human chorionic gonadotropin to the preovulatory follicle. Endocrinology 109, 356-362

Prof. Dr. Elaine Watson

Royal (Dick) School of Veterinary Studies

Easter Bush, Midlothian, EH25 9RG, UK

elaine.watson@ed.ac.uk 